\title{
APPLYING HABERMAS' VALIDITY CLAIMS AS A STANDARD FOR CRITICAL DISCOURSE ANALYSIS
}

\author{
Wendy Cukier \\ Ryerson University \\ Robert Bauer \\ Johannes Keppler University \\ Catherine Middleton \\ Ryerson University
}

\begin{abstract}
It has been proposed that the theory and practice of information systems development could benefit from a more explicit consideration of concepts of rationality. Habermas' communicative rationality has been proposed as an approach to improve the conditions for rational discourse in systems development, thereby improving outcomes (Klein and Hirschheim 1991), and applied at the project level (Ulrich 2001) and to specific episodes of managerial communications (Ngwenyama and Lee 1997). At the same time, it is understood that societal discourses and ideologies shape the external environments of organizational decision making. A variety of approaches has been proposed to analyze these discourses including qualitative techniques for reading or interpreting texts, artifacts, and social practices (Philips and Hardy 2002). This paper examines the way in which Habermasian validity claims can provide an explicit and ethical standard for critical discourse analysis in order to reveal the distortions that shape the institutional environments of technology decision making. It offers an approach to operationalizing Habermas' validity claims for an analysis ofmedia texts related to a case study involving learning technology.
\end{abstract}

Keywords: Discourse analysis, Habermas, institutional theory; ideal speech, learning technology 


\section{INTRODUCTION}

This paper examines media discourses on a technology enabled learning project in an effort to explore ways in which these discourses may shape and reflect technology planning and decision making. Using texts that discuss the "Acadia Advantage" case (a Canadian university's program to bring notebook computing into the classroom), the paper demonstrates how Habermas' validity claims can be used as an analytical framework to guide discourse analysis. The paper contributes to the discussion of technology planning and systems development and to the techniques of discourse analysis in two ways.

(1) Discourses are important to the study of organizations and information systems because they shape the organizational and institutional environments that provide a context for planning and decision making. However, in spite of the long tradition of technology criticism that focuses attention on the construction of reality, there has been limited attention in the information systems literature to the linkages between societal level and organizational discourses.

(2) Despite the growing popularity of discourse analysis among information systems researchers (e.g., Wynn et al. 2003), there has been limited reflection to date on the methodology of discourse analysis. This paper proposes a novel approach to textual analysis grounded in Habermasian discourse ethics. It proposes that the Habermasian notion of the "ideal speech act" can serve as a standard for assessing the rationality of discourse and that Habermas' validity claims can be operationalized for textual analysis that is both rigorous and theoretically sound.

\section{DISCOURSE ANALYSIS AND INFORMATION SYSTEMS}

Discourse is one of the principal ways in which reality is socially constructed and has long been the subject of scholars in sociology, psychology and cultural studies (see, for example, Fairclough 1995; Fiske 1982; Hansen et al. 1998; Hirsch 1986; Inglis 1990; Jensen and Jankowski 1991; van Dijk 1991; Wodak 1989). More recently, attention has focused on exploring the role of discourses and their relevance to organizational studies and management (e.g., Grant et al. 2001, Hardy 2001, Kets de Vries and Miller 1987).

There have also been analyses of information technology discourses at the organizational level (Wynn et al. 2003). For example, Robey and Markus (1984) suggested that elements of the systems design process can be interpreted as rituals that enable actors to appear overtly rational while negotiating to achieve private interests. Orlikowski and Yates (1994) examined genre repertoires in organizational communications, and Päivärinta (2001) applies the genre concept to critical information systems development. Murray (1991) examined discourses of power among IS specialists. Bloomfield and Vurdubakis (1994) examined discourse reflected in information technology consultancy reports. Others (e.g., Boland 1985, 1991; Boland and Day 1989; Butler 19981; Gopal and Prasad 2000; Myers 1995) have applied hermeneutic analysis to aspects of discourse analysis. 
Societal discourses are part of the institutional environment of organizations, and media is an important part of societal discourse. Studies in the social sciences examine the role of media in shaping perceptions of social reality (Gerbner 1977; Lazarsfeld and Merton 1948; Lippmann 1992; McLuhan and Fiore 1968), as well as the structural forces shaping discourse (Chomsky 1989; Foucault 1980). The organizational relevance of the broader societal discourse as a part of the organization's institutional environment has, with varying degree of explicitness, been acknowledged in the organization theory literature (e.g., Czarniawska-Joerges and Joerges 1988; DiMaggio and Powell 1984; Meyer and Rowan 1977; Meyer and Scott 1983). Alvarez (1996) notes that the popularization of knowledge has to do not only with its intellectual merits but also with the political, social, and ideological position and disposition. In general, the links between societal discourses (macro level) and organizational discourses have received limited attention.

The role of discourse in management has been examined by Clegg and Palmer (1996). Abrahamson (1996, 2001) and others (e.g., Furusten 1999) examined the role of management fads and fashions. Philips and Hardy (1997) examined refugee systems, and Hardy, Lawrence and Philips (1998) examined employment services. Calás and Smircich (1991) deconstructed leadership discourse and Bowring (2000) deconstructed institutional theory. Townley (1993) used Foucauldian discourse analysis to explore human resources management. There has been some examination of the discursive practices by some professions (Clegg and Palmer 1996; Meyer and Scott 1992).

There is a well-established tradition in the social sciences focusing on exposing broad societal discourses that surround technology. For example, Ellul (1977) and Winner (1986) examine aspects of the technological imperative that has enveloped society and suppressed technology criticism. Ellul argued that "the human being who uses technology today is by that very fact the human being who serves it" (p. 325). Nardi and O'Day (1999) have examined "the rhetoric of inevitability," a language that represents technological change as unstoppable and unavoidable. Postman (1992), Rose (2003), Stoll (1995), and many others examine the ways in which technology discourses shape perceptions and behavior.

However, there has been relatively little discussion of the role of societal discourses in the information technology literature. Given the importance of ideologies and societal discourses in shaping the institutional environments of organizations, societal discourses surrounding information technology would seem to warrant further exploration (Cukier and Bauer 2002; Cukier et al. 2003). By analyzing the broader societal discourse on information technology, using a framework that is directly linked to rationality in organizational decision making, we make a contribution to narrowing this gap. The paper also provides an explicit discussion of the methodology used to explore the rationality of societal discourses on information technology.

\section{PARADIGMS AND METHODS IN DISCOURSE ANALYSIS}

There have been attempts to categorize approaches to discourse analysis using the concept of paradigms (e.g., Heracleous and Barrett 2001; Philips and Hardy 2002). 
Such typologies distinguish, among other things, interpretative approaches from critical discourse analysis. Interpretative approaches, for the most part, are grounded in the notion that reality is socially constructed, and draw on a wide range of philosophical and linguistic theories of language and approaches to reading texts (which can include the written word or social practices). A number of scholars have applied these approaches to "reading" organizational texts (Boland 1991; Lee 1994), to analyzing metaphor or genre (Orlikowski and Yates 1994), or to deconstruction (Calás and Smircich 1991). These are modes of address that imply specific social uses of communication in relation to particular political and cultural practices (Jensen 1991). According to Burrell and Morgan's (1979) framework for paradigm analysis, the interpretative paradigm is subjective and focused on examining the status quo rather than effecting change. Consequently, it is difficult to make a link between interpretative approaches and improving practice.

In contrast, critical discourse analysis is focused on exposing the deep structures that underlie discourse, particularly power, and is grounded in normative or ethical standards. Its roots are in the Frankfurt school of neo-Marxism and it has been adapted in some forms of radical feminist analysis. Its explicit objectives are to effect radical change. Fondas (1997), for example, undertook a feminist analysis of management writings. Krefting (2001) analyzed the portrayal of women executives in mass media. Generally, the approach to discourse associated with Marxist scholars from the Frankfurt school is critique, the reading of texts, artifacts, or social practices to reveal underlying ideology (Hardt 1992). Foucauldian analysis of social and cultural practices (e.g., Foucault 1980) is difficult to categorize. It is inherently political and focused on exposing power relationships. However, the epistemology underlying Foucault's approach leaves little room for normative or ethical analysis, a criticism leveled at him by Habermas. The principal difficulty in linking current approaches to critical discourse analysis to practice is that they rest on large-scale structural change.

Burrell and Morgan's radical humanist paradigm has tended to be overlooked by typologists of discourse analysis or lumped in with other critical approaches. We argue, however, that its is significantly different and offers a valuable perspective which can be used to improve practice, for while radical humanism focuses, like radical structuralism, on effecting change, its means are different. The change envisaged can occur at the individual level with enlightenment and emancipation as the path. Although Habermas (1984) sprang from the Frankfurt school, his emphasis on the emancipatory power of reason distinguishes him from neo-Marxists. Habermasian discourse ethics offer a strong and unique conceptual framework for understanding communications distortions and for improving practice (Forester 1983). The challenge is finding ways to operationalize the principles into tools for discourse analysis. It is this challenge that is addressed in this paper.

\section{DISCOURSE, DECISION MAKING, AND RATIONALITY}

Most approaches to management and planning rest on notions of rationality. Often these are grounded in Weberian notions of rationality which prioritize the notion of 
efficiency and economic behavior. Rationality is an implicit goal of most information systems development efforts. Klein and Hirschheim (1991) systematically discuss the types of rationality that underlie different approaches to systems analysis and design. They discuss the formal and substantive form of rationality proposed by Weber and its relationship to different system development methodologies.

They maintain, however, that this is only one form of rationality. Communicative rationality is another notion of system rationality, which is focused more on the development of mutual understanding and consensus in the context of the ideal speech situation. This ideal speech situation

is a hypothetical situation which is characterized by a) an open agenda and free access in which all claims and counter claims can be freely examined, b) no asymmetries of knowledge and power...c) a social atmosphere which encourages everyone to express their feelings, to question and examine those feelings... . The opposite of rational communication is distorted communication. (Klein and Hirschheim 1991, p. 167)

The principles of ideal speech are embodied in information systems development methodologies which treat systems analysis and design as a communication and learning process. In order to achieve emancipatory rationality it is necessary to diagnose distorting tendencies in communication. There is a significant body of IS research that draws upon Habermas' work as it relates to information systems development. As noted by Päivärinta (2001), contributors in this area include Klein, Hirschheim. and Lyytinen (e.g., Klein and Hirschheim 1993; Lyytinen and Klein 1985), as well as Ngwenyama (1991) and Ulrich (2001). In addition, Ngwenyama and Lee (1997) undertook an intensive investigation of an episode in the managerial use of e-mail in a company by applying Habermasian validity claims to e-mail messages, and Truex and Klein (1991) outlined an interpretation of information systems as formalized language games based on Habermas.

While the application of the standard of communicative rationality has been discussed in the context of information systems development, it has not been applied to the broader context of organizational decision making about information technologies or to the societal discourses that shape the institutional environment in which decision making takes place. It is understood that discourse on technology mirrors power relations and structures ideology, the "shared, relatively coherent interrelated set of emotionally charged beliefs and norms," which in turn shape the way technology is understood and enacted in organizations (Feldman and March 1981). "Although planners may believe they are acting rationally in adopting new technologies, their decisions actually reflect a pervasive mystique that what can be developed, must be developed" (Attewell and Rule 1984).

Examining societal and organizational discourses provides a means of assessing communicative rationality. As the case study data presented below show, when the ideal speech situation is not realized, communication distortions exist. Forester (1989), writing in the urban planning literature, maintains that revealing such distortions can improve the rationality of communications and, in particular, planning practice. Exposing ideologies to the standards of rational discourse may provide a means of 
reducing their influence on decision making. Habermas maintains that reason may be applied to undistort communications and improve the human condition. By providing an explicit and ethical standard for assessing the validity of communications, Habermas offers a strong and unique conceptual framework that can be applied not only to analyze the distortions in discourse which reflect the dominant ideology and power structures but also to undistort communications, thereby improving practice. While the principles of Habermasian discourse ethics have been invoked in many different discussions of policy development and management, there are limited examples of ways in which these principles can be operationalized and very few examples of their application to the analysis of societal discourse.

\section{RESEARCH QUESTIONS AND METHODOLOGY}

Recognizing the importance of discourse as a means of understanding the decisionmaking context and environment of the Acadia Advantage project, the research questions posed in this study were as follows: What is the nature of the discourse on Acadia University's technology-enabled learning Acadia Advantage project? Are communication distortions evident in this discourse? What can be learned from the Acadia Advantage case study about the development and adoption of technologyenabled learning projects?

In order to investigate these questions, a methodology was devised using Habermas' ideal speech situation and validity claims as the framework to assess the discourse. Specifically, each validity claim was applied as an analytical lens, through which to analyze the texts describing the Acadia Advantage program. The discourses on the Acadia Advantage program considered in this paper are drawn from a total of 57 sources, representing popular, academic, and practical part discourses.

\subsection{Validity Claims and the Ideal Speech Situation}

Following Forester (1983), we adopt Habermas' theory of communicative action as a foundation for our analysis. Forester suggests that this theory allows for (1) empirical analysis of communicative interaction and structural settings; (2) interpretive analysis of meaning; and (3) normative analysis of systemic distortion and violation of the free discourse of humans implicit in the most ordinary communications (p. 236).

Habermas maintains that with the dissolution of a theologically based form of substantive ethics, a new form of secular, procedural morality emerges "based on moral agreement that expresses in rational form what was always intended in the symbolism of the holy" (Habermas cited in Cannon 2001, p. 101). The basis of this morality is communicative ethics. "Social integration no longer takes place directly via institutionalized values but by way of inter-subjective recognition of validity claims raised in speech acts" (Habermas cited in Cannon 2001, p. 101). Discourse ethics asserts that morality is based on a pattern inherent in the mutual understanding of a language. In this way Habermas avoids the threat of relativism by invoking a standard for communication which is universal and unconditional (Cannon 2001) yet at the same time dynamic and grounded in the social world (Duquenoy et al. 1998). A universally valid ideal speech 
situation may be used to assess the legitimacy of normative claims; and this in turn forms the basis for his notion of communicative or discursive ethics.

Habermas sets out four tests, or validity claims, that must exist in order for the ideal speech situation to be realized. An example of the application of the validity claims to the speech act is an examination of possible responses to a simple request. If a professor asks a student, "Would you please bring me a glass of water?," the request could be rejected on the basis of assumptions about truth, clarity, sincerity, and legitimacy ${ }^{1}$ implicit in that speech act (Habermas 1979, 1984). Assessing the truth assumption would involve consideration of the objective facts in the speech act. If there were no water available in the building, then the truth claim would not be achieved. If the request were unclear (for example, there was no shared system of meaning between the two participants as the professor made the request in English to a student whose English was poor), then clarity was not achieved. Sincerity is assessed by considering the congruence of the expressed meaning and the speaker's agenda. For instance, was the request a genuine request for a glass of water, or was it an opportunity for the professor to demonstrate authority over the class by demanding an obedient response? Legitimacy in this case would apply to the appropriateness of the implied relationship among the parties to the speech act, e.g., is it a student's duty to serve a professor in the requested manner?

According to Habermas, rational action is the result of communicative action when actors do not violate any of the validity claims in their speech acts. This ideal speech situation results in undistorted communication and builds comprehension, trust, knowledge, and consent. In contrast, distorted communication results in misrepresentation, confusion, false assurances, and illegitimacy.

\subsection{Operationalizing Habermas' Validity Claims to Assess Communicative Rationality}

Habermasian communicative rationality is a useful standard for the analysis of discourse because it enables us to apply normative standards to expose the distortions in discursive practices and so improve practice. Habermas provides a way of understanding the effects of the discourses in which we participate. But Habermas does not propose a methodology for discourse analysis. Difficulties in linking discourse ethics theories with practical concerns have been explored (see, for example, Blaug 1999; Cannon 2001). Nevertheless, Habermas' validity claims do have strong appeal as a conceptual tool for empirical research. Their theoretical foundation is strong, and the validity claims are accessible, as truthfulness, clarity, sincerity, and legitimacy are easily understood.

${ }^{1}$ Note that terminology varies somewhat when describing Habermas' validity claims. In Communication and the Evolution of Society, the four validity claims are translated as truth, rightness, truthfulness, and comprehensibility (Habermas 1979), a translation used by Ulrich (2001) in his discursive approach to information systems development. Forester (1989) uses comprehensibility instead of clarity, but otherwise follows the terminology used in this paper. 
Table 1. Communicative Distortions (From Forester 1989, p. 150)

\begin{tabular}{|l|l|l|l|l|}
\hline \multicolumn{1}{|c|}{$\begin{array}{c}\text { Practical } \\
\text { Level }\end{array}$} & $\begin{array}{c}\text { Comprehen- } \\
\text { sibility }\end{array}$ & \multicolumn{1}{|c|}{ Sincerity } & \multicolumn{1}{|c|}{ Legitimacy } & \multicolumn{1}{|c|}{ Truth } \\
\hline Face-to-face & $\begin{array}{l}\text { Ambiguity, } \\
\text { confusion, } \\
\text { lack of sense }\end{array}$ & $\begin{array}{l}\text { Deceit, } \\
\text { insincerity }\end{array}$ & $\begin{array}{l}\text { Meaning taken } \\
\text { out of context }\end{array}$ & Misrepresentation \\
\hline Organization & $\begin{array}{l}\text { Use of jargon } \\
\text { to exclude } \\
\text { public }\end{array}$ & $\begin{array}{l}\text { Rhetorical } \\
\text { reassurances, } \\
\text { false } \\
\text { expression of } \\
\text { concern, hiding } \\
\text { motives }\end{array}$ & $\begin{array}{l}\text { Unresponsive- } \\
\text { ness, assertion } \\
\text { of rationaliza- } \\
\text { tions, domi- } \\
\text { nance by } \\
\text { professionals }\end{array}$ & $\begin{array}{l}\text { Information with- } \\
\text { held, responsibility } \\
\text { obscured, need } \\
\text { misrepresented }\end{array}$ \\
\hline $\begin{array}{l}\text { Political } \\
\text { Economic } \\
\text { Structure }\end{array}$ & $\begin{array}{l}\text { Mystification, } \\
\text { complexity }\end{array}$ & $\begin{array}{l}\text { Manipulation } \\
\text { of the public } \\
\text { good }\end{array}$ & $\begin{array}{l}\text { Lack of } \\
\text { accountability, } \\
\text { legitimization } \\
\text { through empty } \\
\text { rhetoric rather } \\
\text { than by active } \\
\text { participation }\end{array}$ & $\begin{array}{l}\text { Policy possibilities } \\
\text { obscured, withheld } \\
\text { or misrepresented, } \\
\text { ideologicalclaims } \\
\text { such as "public } \\
\text { ownership is always } \\
\text { inefficient" }\end{array}$ \\
\hline
\end{tabular}

In order to operationalize Habermas' validity claims, a combination of textual analysis techniques may be employed (Cukier and Bauer 2002; Cukier et al. 2003). While Forester (1989) does suggest ways in which communicative distortions may occur in face-to-face, organizational, and political/economic structures and ways of correcting communicative distortions, his work remains at the conceptual level and is not applied specifically to discourse (see Table 1).

To assess Habermas' validity claims through an examination of texts, a series of questions was developed to facilitate identification of truth, sincerity, clarity, and legitimacy claims in these texts. These questions formed the basis of a coding scheme used to identify the elements of ideal speech present in the discourse. Careful readings of the texts produced data sets coded by validity claim, facilitating content analysis that provided concise measurement of the speech acts constituting each claim. Subsequent analysis allowed for consideration of communication distortions by examining the instances where the ideal speech situation was not realized. Our focus was on understanding the range of texts within the discourse to understand overall patterns of communicative rationality, rather than on detailed analysis of specific passages.

Identification of truth claims within the discourse was guided by a search for objective facts. Michalos' (1986) tests for logic were helpful in developing specific questions, including what are the basic arguments? Are the issues and options clearly defined? What evidence has been provided to support these arguments? Has the relevant information been communicated without distortion or omission? Are there ideological claims which are unexamined? 
Table 2. Summary of Validity Claims and Corresponding Discourse Dimensions

\begin{tabular}{|l|l|l|l|}
\hline \multicolumn{1}{|c|}{$\begin{array}{c}\text { Validity } \\
\text { Claim }\end{array}$} & \multicolumn{1}{|c|}{ Result } & \multicolumn{1}{c|}{ Distortion } & \multicolumn{1}{c|}{$\begin{array}{c}\text { Speech } \\
\text { Dimensions }\end{array}$} \\
\hline $\begin{array}{l}\text { The content of the presupposi- } \\
\text { tions of what is said be factual or } \\
\text { true. }\end{array}$ & Truth & Misrepresentation & $\begin{array}{l}\text { Argumentation and } \\
\text { evidence }\end{array}$ \\
\hline $\begin{array}{l}\text { The speaker is honest (or } \\
\text { sincere) in what she says. }\end{array}$ & Sincerity & False Assurance & $\begin{array}{l}\text { Metaphors and } \\
\text { connotative words }\end{array}$ \\
\hline $\begin{array}{l}\text { What is said is linguistically } \\
\text { intelligible and comprehensible. }\end{array}$ & Clarity & Confusion & $\begin{array}{l}\text { Rhetoric and } \\
\text { semantic rules }\end{array}$ \\
\hline $\begin{array}{l}\text { What the speaker says (and } \\
\text { hence does) is right or appro- } \\
\text { priate in the light of existing } \\
\text { norms or values. }\end{array}$ & Legitimacy & Illegitimacy & Use of experts \\
\hline
\end{tabular}

Sincerity claims are identified through the use of rhetorical devices. Examining the choice ofmetaphors, adjectives, and connotative vocabulary used in the texts may reveal nuances not apparent on cursory reading. "Stylistic choices also have clear social and ideological implications, because they often signal opinions of the reporter about news actors and news events as well as properties of the social and communicative situation" which are not directly expressed (van Dijk 1991, p. 116). Coding for sincerity claims sought to identify instances in which metaphors or language usage could influence interpretation or understanding of the Acadia Advantage project and technology, paying particular attention to instances where metaphors or language might promote or suppress understanding or create false assurances.

Clarity was assessed in the usage of jargon, unfamiliar terminology, or incomprehensible language. Clarity is achieved when these obfuscations are absent.

In the area of legitimacy, coding focused on identifying texts that indicated participation in the discourse. To whom was legitimacy accorded in the texts? Who was considered an expert, and on what basis? What was assumed or implied in the discourse? How were decisions legitimized? Once coding was complete in this section, it was then possible to consider questions of absence, including which groups and viewpoints were marginalized or excluded from the discourse. What was missing or suppressed?

Table 2 summarizes the dimensions of discourse used to assess the validity claims. One of the distinct advantages of this approach is that the speech dimensions can be analyzed using both qualitative and quantitative textual analysis techniques. In combination, these add to the power of this approach to discourse analysis. Different approaches to reading text are not mutually exclusive and applying multiple perspectives to text may address the limitations of individual techniques in isolation. Kracauer (in Larsen 1991) insisted that a reading of a text necessarily involves an act of interpretation which, like other readings, is based on specific assumptions to be made explicit in the reading. "Critical discourse analysis is a particular epistemological orientation to dis- 
course and tends to be associated with a qualitative 'reading' or artifacts" (Fairclough 1995). Critical theorists have tended to reject quantitative strategies for determining the content or meaning of media messages (Kracauer) given the importance of considering both the manifest and latent meanings. However, even Kracauer granted that quantitative studies might serve as a supplement to qualitative analysis. The sheer volume of mass media texts poses problems in terms of heterogeneity as well as quantity. We find other examples of mixing methods. Herman and Chomsky (1988), for example, employ a wide range of techniques including content analysis to demonstrate ways in which the mass media is used to manufacture consent. A major criticism often leveled at discourse analysis is that it is selective or lacks rigor (Philips and Hardy 2002). Combining qualitative and quantitative approaches is one way of responding to these criticisms.

Once the discourse has been coded, questions guiding analysis include what distortions or misrepresentations have occurred? Why have they occurred? What might undistorted communication look like? These questions are addressed below.

\section{METHODS IN ACTION: THE ACADIA ADVANTAGE CASE STUDY}

The texts analyzed here refer to the Acadia Advantage project. In 1996, the President of Acadia University (a 3,500 student liberal arts university in Wolfville, Nova Scotia, Canada) announced a plan to wire classrooms, promoting the development of Web-based curricula, and requiring students to lease portable computers. The Acadia Advantage became the centerpiece of the university's marketing and has been showcased by IBM in its ThinkPad University marketing efforts. It is regarded as a model for notebook or ThinkPad computing at many other post secondary institutions and has received considerable media coverage.

For text selection, we used two multidisciplinary full-text databases (EBSCO, including the Academic Search Full Text Elite segment, and ProQuest, including ABI/Inform Global, Applied Science and Technology Plus, Periodicals Abstracts II, and ProQuest Telecommunications) as well as several subject-specific electronic resources (e.g., Gale Directory of Databases, Faerber 1999). The search statement was identical in all databases: (Acadia University) AND (Technology OR Advantage). The time period searched was from 1993 to June 1998. The search, international in scope, produced a master list of 72 articles in different periodicals. Articles that did not actually relate to the Acadia Advantage technology-enabled learning project were excluded, resulting in 57 relevant articles that were used in this analysis (see Appendix A for a list of the sources).

\subsection{Truth: What Are the Facts? Are the Arguments Supported with Evidence?}

The analysis reveals certain patterns in argumentation (see Table 3). Many of the statements regarding the program are essentially descriptive-all students received an IBM laptop computer and software (63 mentions) which they leased for $\$ 1,200$ per year 
for a total of $\$ 5,055$ in tuition (23). The campus was wired to provide access to the Internet everywhere (18) and courses were redesigned to integrate technology (14).

Claimed positive effects for participating students included improved quality of learning, access to more information from the Internet, improved technology skills, and improved equity and access. Positive effects were also claimed for the university (e.g., industry partnerships) and for industry (e.g., increased educational markets). Negative effects claimed for students included tuition, which was the highest in the country and might be a barrier to access. Other negative effects claimed were the additional investment in infrastructure by the university and the potential negative effects for society such as privatization of education. The negative effects for faculty included the increase in workload without compensation. The principal claims are shown in Table 3.

To assess the truthfulness of the discourse, we will consider some of the claims, the evidence used to support them, and the argumentation (inductive and deductive reasoning). For instance, while proponents of the Acadia Advantage insist that it is primarily an academic initiative aimed at improving the quality of learning, little evidence is provided to support the claims. A number (8) of articles report that the program has resulted in improved student performance, some with dramatic headlines: "Acadia's Wired Students Soar to the Top of the Class" (Halifax Daily News 1997) or, "Technology is Getting Good Grades with Faculty and Students at Acadia University in Nova Scotia" (Pearsall 1998). Only two articles mention significant caveats in the study comparing wired and non-wired students, including the absence of controls for class size and consideration of whether or not the students were specializing in the discipline. Class sizes (96 versus 20) and teaching methods were very different (Pearsall 1998, p. 11). Even more important, the 96 non-Acadia Advantage students in the Physics course under study were mostly non-physics majors while 80 percent of the much smaller class of 20 Acadia Advantage students were Physics majors (McLaughlin 1997).

The claim that improved learning is a consequence of the use of laptop computing is frequently inferred. Many articles repeat the claim that the Acadia Advantage increased interactivity in the classroom (4), produced more learner- centered instruction (8), and promoted more practical and studio-oriented work (10). "The lecture hall is passive learning, it's boring.... We need students who are actively involved. They should be discussing, analyzing, problem solving" (Noakes 1996, p. 14). The suggestion here is that laptops alone created increased interactivity. While laptops were certainly a catalyst, increased interactivity appears to have been furthered by smaller classes coupled with extensive (and time consuming) faculty efforts to redesign courses. Acadia's technology initiative may have provided an opportunity for restructuring which produced benefits, but it does not follow that investing in laptop computers was the principal factor producing these benefits. Similarly, benefits like reduced note taking (5) and increased access to information (22) could be achieved by other means, although there is no evidence that these identified benefits are in themselves valuable.

Watters et al. (1998) claim that the Acadia Advantage program is "One example of the new class of learning support tools needed to take advantage of the reality of student centered mobile computing." However, their article offers a mere description of activities with no analysis of objectives or outcomes and is circular, arguing that the tools are needed to take advantage of the technology rather than considering the variety of means which might be used to achieve the ends of enhanced learning. 
Table 3. Principal Claims Regarding Cause (AA Program) and Effects

(Number of Text Segments)

\begin{tabular}{|c|c|}
\hline \multicolumn{2}{|l|}{ Descriptive Statements } \\
\hline All students receive an IBM laptop computer and software & 63 \\
\hline $\begin{array}{l}\text { Students must pay } \$ 1,200 \text { per year to lease a computer } \\
\text { ( } \$ 5,055 \text { tuition including computer) }\end{array}$ & 23 \\
\hline Campus wired to provide access to Internet anywhere & 18 \\
\hline Courses redesigned to integrate technology & 14 \\
\hline \multicolumn{2}{|l|}{ Claimed Positive Effects for Students } \\
\hline \multicolumn{2}{|l|}{ Improved quality of learning } \\
\hline - More practical and studio work & 10 \\
\hline - Improved performance of Acadia Advantage students versus traditional & 8 \\
\hline — Learner centered—changed relationship between students and teachers & 8 \\
\hline - More interactive learning, lectures decreased & 4 \\
\hline — Student enthusiasm & 4 \\
\hline - PowerPoint presentations & 1 \\
\hline \multicolumn{2}{|l|}{ More information from the Internet } \\
\hline - Increased access to information sources & 22 \\
\hline - More communication, collaboration among students & 5 \\
\hline \multicolumn{2}{|l|}{ Technology skills } \\
\hline — Students gain experience with computers and Internet & 7 \\
\hline \multicolumn{2}{|l|}{ Equity/Access } \\
\hline — Students have equal access to computing resources & 3 \\
\hline $\begin{array}{l}\text { - Students receive identical software and hardware which is regularly } \\
\text { upgraded and supported }\end{array}$ & 2 \\
\hline - Technology is part of tuition therefore tax deductible & 1 \\
\hline \multicolumn{2}{|l|}{ Claimed Positive Effects for University } \\
\hline Partnerships with IBM, Microsoft, MT\&T, 3Com & 4 \\
\hline University can offload costs of upgrading technology to the students & 2 \\
\hline Corporate donations to capital campaign & 2 \\
\hline Leading edge & 2 \\
\hline Contributions a marketing effort & 2 \\
\hline \multicolumn{2}{|l|}{ Claimed Positive Effects for Industry } \\
\hline Grow education market & 2 \\
\hline \multicolumn{2}{|l|}{ Claimed Negative Effects for Students } \\
\hline Tuition is the highest in the country & 13 \\
\hline High tuition may be a barrier to accessing education & 5 \\
\hline Only students leasing IBM computers have access to Acadia Advantage courses & 2 \\
\hline Off campus students pay additional $\$ 25$ per month for Internet access & 2 \\
\hline Students pay $\$ 4,800$ over 4 years and must return computer & 2 \\
\hline
\end{tabular}




\begin{tabular}{|l|r|}
\hline Claimed Negative Effects for University & 21 \\
\hline Labor unrest & 6 \\
\hline Wiring campus required additional investment by university of \$16 to 20 million & 1 \\
\hline Additional investment in "sandbox" of \$300,000 & \\
\hline Claimed Negative Effects for Society & 3 \\
\hline Privatization, corporatization of education & 1 \\
\hline Funds diverted from education to IT companies & 7 \\
\hline Claimed Negative Effects for Faculty & 1 \\
\hline Large increase in course development time borne by faculty & 3 \\
\hline Increased communication with students adds to workload & 3 \\
\hline Questions regarding effects and their causes & 2 \\
\hline $\begin{array}{l}\text { Less costly alternatives are available to provide access to computers and Internet } \\
\text { information sources }\end{array}$ & 2 \\
\hline Technology no substitute for critical thinking & \\
\hline More information is not necessarily better & \\
\hline $\begin{array}{l}\text { Improved performance as a result of course redesign, small class, and differences in } \\
\text { students (e.g., majors) not technology }\end{array}$ & \\
\hline
\end{tabular}

It is also claimed that the program increases access to technology for students (3). "Parents often end up buying their children computers for university, but not every student gets one. But at Acadia, the playing field is level. Students have equal access to learning" (Murphy 1998, p. 34). "For the first time in the history of Acadia," Bruce Cohoon, Director of Public Affairs at Acadia University, stated, "every person involved in the program has equal access to information and technology" (Domet 1997, p. 1). Invoking a level playing field is a powerful appeal to metaphor, as discussed below, but it is hardly an accurate description of the Acadia program. As a few articles (5) note, by requiring students to pay an additional $\$ 1,200$ per year, Acadia may have created a barrier to accessible education and technology.

In summary, when Habermas' first standard, that of truth, is applied, we find unsupported claims and faulty logic, such as the inductive fallacies of faulty analogy and "false cause" (Michalos 1986). In many cases, the specific causal link between the claimed benefits for students and the Acadia Advantage program (i.e., the mandatory leasing of laptop computers) is unclear. The fact that the results attributed to Acadia Advantage might have been achieved through other means, such as significant investment in curriculum redesign, smaller teacher/student ratios, and access to other kinds of computing and Internet resources, is seldom discussed. Some of the benefits claimed are more clearly associated with access to computers and the Internet than others. However, the ThinkPad solution selected by Acadia may not have been the most affordable or equitable means of providing access to computers and the Internet. The total costs (including the investment in infrastructure and labor required to redesign the courses) or alternative approaches are almost never considered. Only three articles raise questions about the argumentation of the proponents and, in particular, question the link between claimed causes and effects (Table 3 ). Most of the articles simply replicate them. 


\subsection{Clarity: Is What Is Said Intelligible and Comprehensible?}

There are a number of ways in which clarity may be undermined and confusion may be created, intentionally or unintentionally. The fallacy of jargon is committed when instead of being given accurate and comprehensible descriptions of a product, we are given technical terms that make the claim seem stronger, more important, or valuable (Michalos 1986). Several of the articles use technology terms that may obscure more than they clarify. In a number of the Acadia Advantage texts there is a detailed description of the leading edge technology components with no explanation as to why they are useful or important.

While, naturally, the assumptions of the reader's level of technical expertise may vary with the publication, there is virtually no explanation of either the meaning or importance of the technologies in any of the articles examined. Technical terms pervade the discourse, but are seldom explained, as this example shows.

A campus wide Asynchronous TransferMode (ATM) switching solution enabled students and faculty to gather information electronically and to better communicate. Now in its second year, the program is being called a great success. About 4,500 "drops" have been installed all over campus, everywhere from classroom seats to libraries, cafeterias and students lounges. Drops are places where students can connect their laptops to the network via Ethernet locally and the ATM backbone. By the end of the four-year roll-out period, 8,000 of these connection points will be installed in and around campus. (Joy 1998, p. 18).

In addition, texts frequently (115 mentions) apply a wide range of adjectives with positive associations-new (11), innovative (11), wired (8), award-winning (6), hi-tech (6), ambitious (2), pioneering (4), exciting (5), etc.- - which tend to reinforce a positive view of the program, and imply that new and innovative are desirable attributes. Although several articles do suggest there are problems associated with the program, adjectives that invoke skepticism - such as controversial (1), expensive (5), or scary (3) - are seldom used. Table 4 provides a summary of adjectives found in the discourse.

It may be argued the preponderance of technical jargon is not only a barrier to understanding but part of a pervasive technological mystique. This mystique can serve to elevate those who are part of the technological priesthood while excluding those who do not understand from meaningful participation in the discourse. This leaves them with essentially two alternatives: completely rejecting the propositions or accepting them uncritically, which also has implications for legitimacy, discussed below.

\subsection{Sincerity: Is What Is Said What Is Meant? What Is Implied/Invoked?}

The sincerity of a speech act may be assessed in several ways. Essentially, sincerity requires congruity between what is said and what is meant or the intention underlying and the intention expressed in the speech act. There is no hidden agenda in a sincere speech act. 
Table 4. Connotative Language - Number of References

\begin{tabular}{|c|c|}
\hline Term & \# \\
\hline \multicolumn{2}{|l|}{ Subjects } \\
\hline Acadia Advantage & 83 \\
\hline Program & 82 \\
\hline Project & 24 \\
\hline Initiative & 6 \\
\hline Innovation & 4 \\
\hline Investment & 4 \\
\hline Revolution & 3 \\
\hline Virtual Classroom & 3 \\
\hline Experience, Vision, Evolution & 2 \\
\hline $\begin{array}{l}\text { Cyber-campus, Huge Attraction, Undertaking, Great Success, Opportunity, } \\
\text { Cyber-push, Paradigm Shift, Campaign, Excellent Plan, Leader, Comprehensive } \\
\text { Deal, Cyber-club, Hype, Best Thing }\end{array}$ & 1 \\
\hline \multicolumn{2}{|l|}{ Adjectives-Positive } \\
\hline Innovative & 11 \\
\hline New & 11 \\
\hline Wired & 8 \\
\hline Hi-tech & 6 \\
\hline First & 6 \\
\hline Award Winning & 6 \\
\hline Pioneering & 4 \\
\hline Exciting & 5 \\
\hline Electronic, Vaunted, Cyber & 3 \\
\hline $\begin{array}{l}\text { Lauded, Laptop, Significant, Sophisticated, Forefront, Future, Ambitious, Ground } \\
\text { Breaking, Academically Driven, Unique }\end{array}$ & 2 \\
\hline $\begin{array}{l}\text { Revolutionary, Radical, Great, Effective, Latest, Large, Leading Edge, Dynamic, } \\
\text { Ambitious, Superb, Online, Top Ranked, Technological, Highly touted, Coveted, } \\
\text { Computer-oriented, Affordable, Up to date, Information Age, Most, Novel, } \\
\text { Advanced, Selective, Special, Top of the Class, Recently Approved, Major, } \\
\text { Modern, Heralded }\end{array}$ & 1 \\
\hline \multicolumn{2}{|l|}{ Adjectives-Negative/Ambiguous } \\
\hline Expensive & 5 \\
\hline Scary & 3 \\
\hline Mandatory & 2 \\
\hline Compulsory, Pricey, Controversial, Multimillion dollar & 1 \\
\hline
\end{tabular}


Regardless of the denotative content of the articles, certain perspectives are implied or reinforced through connotative language, imagery, and metaphor. Specific nouns used for the project are instructive. All of the articles make repeated references to the use of laptop computers at Acadia as the Acadia Advantage (83), thereby reinforcing the benefits of the program. They often refer to it as a program (82) or a project (24) but also use terms that evoke a positive response-initiative (6), innovation (4), and investment (4).

The dominant metaphor the articles reinforce is the revolution, as in "the wired revolution" or the "techno-revolution." The Acadia Advantage is new, innovative, exciting, and pioneering, while the critics are defending old or traditional approaches. Critics of the technology are cast as "fighting a rearguard action." Many faculty members and administrators see computers as a threat to centuries-old traditions of pedagogy. "There is great irony to this," adds Tapscott, "It's not technology that's the threat. It's the status quo, if the universities don't reinvent themselves, they will be replaced" (Bergman 1998, p. 66).

Sometimes, a simple choice of words has a profound impact on the interpretation of a speech act. For example, several of the texts say or imply that Acadia gave computers to students without mentioning the cost. For example, "The President has been credited with putting Acadia at the technological forefront of academia with the Acadia Advantage program, in which every student will have a laptop computer" (McLaughlin 1998, p. 4). Or, "All first year students are being equipped with sophisticated software and Internet access. By 2000 all the full time undergraduate students will have a computer" (Sommers 1997, p. C5).

In addition, the connotative power of language can be used to reinforce the positions of certain actors and to marginalize others. It seems that language is often used to undermine the credibility of the critics of the program, particularly in the discussions of a labor dispute. "Many professors bristled at being told that they must employ new technology in their classrooms. 'The administration wants to require every faculty member to use the Acadia Advantage,' complained the faculty association president" (Bergman 1998, emphasis added). In contrast the President is cast as a strong and principled leader, an innovator, a visionary.

Proponents of the Acadia Advantage invoke metaphors and images with powerful associations regardless of their appropriateness. For example, the claim that the Acadia Advantage creates a level playing field appeals to powerful emotions and values such as improving accessibility and equity when it may be argued that the program does precisely the opposite.

One may also question the sincerity of a speech act based on evidence of unstated motives or hidden agendas. Consider, for example, the efforts to "spin" the costs of the program. One article notes that when the author suggested that the Acadia Advantage is actually a very effective way for the university to offload systems costs to students, Bruce Cohoon (Director of Public Affairs, and author of the level playing field metaphor) responded, "Let's not call it an extra expense... .Tuition at Acadia is $\$ 5055$ a year period. It just happens that tuition includes a $\$ 3700$ laptop computer and $\$ 16$ million worth of infrastructure behind it" (Pearsall 1998:12). 


\subsection{Legitimacy: What Is Privileged? What Is Missing?}

The analysis of legitimacy centers around what was missing in the discourse. Texts concerning the Acadia Advantage provide generous information about its potential positive effects while slighting information about total costs, disadvantages, and the basis of opposition to the program. The analysis of the number of statements related to the benefits of the program (regardless of their truthfulness discussed above) compared to the statements related to the disadvantages, or the costs of the program reveals this imbalance (see Table 3). Only two articles had more statements related to the costs and disadvantages than benefits; one focused on the accessibility issue and another on the faculty association's objections. Some articles, including the academic ones, had no discussion of costs or disadvantages whatever. In most, the only cost mentioned was the $\$ 1,200$ extra tuition students must pay.

Only one article mentions a $\$ 300,000$ sandbox program, or the faculty time needed to develop the courses. In most cases we are told that these expenditures are good investments and paying dividends. We are also told that folding the costs of computers into tuition makes it tax deductible. In the majority of articles, benefit statements outnumbered cost statements by more than 3 to 1 .

At Acadia, students who did not acquire their ThinkPad computer through the IBM leasing program were denied access to Acadia Advantage course material (Tausz 1996), a point mentioned in only two articles. Only three of the articles explain that there are other ways students could be given access to the benefits of computing and the Internet, such as allowing access to other brands of computers, other terminals, labs, used computers, or wireless technology.

There is evidence that such selective silence also relates to groups affected by the program. A total of 16 articles were specifically focused on the labor dispute and leadership review at Acadia and mentioned the Acadia Advantage. Generally, the faculty association president was quoted in this context. While the faculty repeatedly stated support for the program in principle, their concerns regarding the amount of time required to redevelop courses (estimated at 200 hours per course) are mentioned in only seven. Other concerns related to accessibility are found in only five articles. Bargaining issues, e.g., parity in wages, which were 16 percent below other universities, are mentioned only in two local stories. Not only are these perspectives underrepresented but they are marginalized through the subtle use of connotation (see above) which implies that an "award winning technological initiative" is being used as a bargaining chip, or attacked out of "blind resistance to change" rather than principles.

In any labor conflict the union will use every lever they have. It may be disappointing, certainly in an academic environment, but is not surprising.... Really it's about change and moving the yardsticks and there are those who are resistant to that. (Lewington 1998, p. A6)

Several articles discuss the corporate partnerships but only a few texts examine what corporations actually stand to gain. One calls it an IBM deal (Tausz 1996). Another tells us 
IBM Canada Ltd., a corporate partner in the Acadia Advantage program, is promoting the institute as the place in Canada where expertise in the application of information technology to the curriculum resides....They are well ahead of other post-secondary institutions in Canada and they're willing to share what they've learned. We direct both potential and existing clients to Acadia so they can see what their peers are doing. (Sommers 1997, p. C5)

Acadia may or may not be at the forefront of effective technology-enabled learning, but it is an important IBM customer. Not only was the value of the Acadia Advantage program anticipated to be $\$ 4$ million per year by 2000 , the potential marketing implications were likely even more significant. Acadia policy guarantees IBM a monopoly because only students to whom Acadia has issued a ThinkPad will be enrolled in the notebook courses. Maritime Telephone and Telegraph has exclusive rights to communications and 3Com built the network. One article notes that IBM and MT\&T made $\$ 4$ million in in-kind donations to the University's capital campaign. Only two of the articles link the program to privatization.

Another measure of legitimacy is provided through consideration of who is included or excluded when authorities are cited. While there are legitimate reasons why some perspectives on the project may be more valid than others, it appears that certain perspectives are privileged and others marginalized. For example, almost half of the articles citing experts quote administrators. In all, 29 articles contain 62 statements by administrators regarding the program. In comparison, only 13 articles cite faculty members, a total of 31 times. Interestingly enough, more than one third of the faculty statements (12) come from a single instructor. Students, who are supposed to be the principal beneficiaries of the program, are cited in 8 articles a total of 13 times. In addition, several articles include comments from other experts (5) and vendors (3).

\section{DISCUSSION}

To summarize, our findings suggest that there are communication distortions in the published texts on technology in education at Acadia University. The information provided in the published texts is highly selective and at times misleading. The emphasis is on benefits rather than costs; in particular, the cost of the IT infrastructure and course redesign appear downplayed. In addition, alternatives to the program are widely ignored. In cases where there are apparent improvements in learning and teaching, there is little effort to establish causes. For example, benefits are attributed to the introduction of the technology even when reduced class size and intensive instructional redesign seem to have played a significant role. This effectively silences discussion of any way of improving pedagogical quality other than through investment in information technology. Similarly there is no acknowledgment that alternative ways of providing computing technology and Internet access exist other than by leasing IBM ThinkPads. The metaphors and images reinforce notions of the technological imperative and of progress as a value in itself. The dominant voices are those which support the program; critics are marginalized both subtly and overtly. While one might expect distortions in popular media and in trade publications funded by the private sector, we would expect more rigor and balance in the two peer-reviewed academic publications included in this study. 
Table 5. Authorities Cited-Number of Articles and Statements

\begin{tabular}{|l|c|c|}
\hline \multicolumn{1}{|c|}{ Authority } & $\begin{array}{c}\text { Articles } \\
\text { citing }\end{array}$ & $\begin{array}{c}\text { Total } \\
\text { citations }\end{array}$ \\
\hline Administrators (total) & $\mathbf{2 9}$ & $\mathbf{6 2}$ \\
\hline President & 8 & 15 \\
\hline Vice President & 1 & 3 \\
\hline Dean of Arts & 2 & 3 \\
\hline Coordinator of Acadia Advantage Program & 7 & 20 \\
\hline Director of Development & 2 & 3 \\
\hline Director of Computing & 2 & 5 \\
\hline Director of Institution on Technology and Teaching & 2 & 4 \\
\hline Director of Media Relations & 5 & 9 \\
\hline $\begin{array}{l}\text { Vendors (total) } \\
\text { Microsoft, 3M, and IBM }\end{array}$ & $\mathbf{3}$ & $\mathbf{3}$ \\
\hline Other experts (total) \\
$\begin{array}{l}\text { Neil Postman, Linda Harasim, Don Tapscott, David } \\
\text { Johnston, and Tony Bates }\end{array}$ & $\mathbf{4}$ & $\mathbf{7}$ \\
\hline Faculty (total) & $\mathbf{1 3}$ & $\mathbf{3 1}$ \\
\hline Union Presidents (2) & 6 & 12 \\
\hline Other Faculty (4 different) & 7 & 19 \\
& & $\begin{array}{c}12 \\
\text { one faculty } \\
\text { member })\end{array}$ \\
\hline Students (total) & $\mathbf{8}$ & $\mathbf{1 3}$ \\
\hline Student Union Presidents (2) & 3 & 6 \\
\hline Other Students (4) & & 7 \\
\hline
\end{tabular}

Instead, they merely reinforce our initial comments regarding the need for a critical perspective. The relative power of the various actors engaged in this discourse, what is at stake, and the role of the suppliers of technology in this \$3 trillion market cannot be ignored.

While examining reproduction of the discourse is beyond the scope of this paper, we see evidence of the rhetoric of the Acadia Advantage echoed in other forms. For example, when Canada's Sheridan College introduced its mandatory laptop program, it too talked about the Acadia Advantage and how the technology would produce a level playing field. Government documents, the popular press, and even academic journals reinforce the argumentation about advantages (regardless of the absence of evidence), the metaphors, and privilege certain voices. Vendor-sponsored conferences, publications, and Websites use these as part of their marketing strategy. The reproduction of the discourse is mirrored extensively (Cukier and Bauer 2002). 


\section{LIMITATIONS OF THE STUDY}

This study makes contributions to the discussion of information technology and to the techniques of discourse analysis but is not without limitations. First, the scope of the analysis is very small, with its focus on a particular learning technology project over a limited time period. As such, a broader study would be needed to understand the extent to which the patterns identified are reflected in the broader societal discourse. Second, while we maintain that societal discourses as manifest in media provide part of the environment of organizational decisions about technology, the link is based on institutional theory rather than empirical study. The extent to which the media discourses regarding the Acadia Advantage shape and reflect the organizational discourse needed further investigation. In addition, as it is a retrospective analysis, it has little value for improving information technology decision making at Acadia; rather, it provides insights which might be relevant in other contexts. Finally, while the effort to operationalize Habermasian validity claims to textual analysis is defensible, the mapping of the validity claims to specific dimensions of textual analysis is problematic. For example, while metaphors are used as an indicator of sincerity, that is, the link between what is said and what is meant-we cannot impute motives. That is, one cannot suggest that the use of metaphor is a deliberate effort to deceive as they are pervasive and all but invisible.

\section{CONCLUSION}

Other scholars have insisted on the importance of applying standards of communicative rationality to information systems development at the organizational level. We have suggested that the same standard needs also to be applied to the broader societal discourses which form the context of organizational decision making. Institutional theory tells us that organizational behavior is shaped by the institutional environment. However, as Abell (1991) argues, a recognition of institutional isomorphism need not lead to a complete rejection of rational choice theory. We agree with Forester that Habermasian communicative rationality is an appropriate standard to apply in an effort to expose the communications distortions that suppress common sense. We suggest that further work examining the relationship between the levels of societal and organizational discourses would be a fruitful area of investigation.

The conceptual framework we have developed, building on Forester's interpretation of Habermas' communicative ethics and, specifically, Habermas' validity claims can provide a standard that can be applied systematically to the analysis of discourse in order to identify communication distortions. While not perfect, we suggest ways in which the standards of truth, clarity, sincerity, and legitimacy can be applied to texts using a combination of quantitative techniques (e.g., content analysis) as well as qualitative approaches. This approach may help respond to some of the criticisms leveled at critical discourse analysis techniques.

The example of the Acadia Advantage case was provided to offer an example of how this approach could be operationalized in order to reveal distortions in the discourse regarding learning technology. 


\section{REFERENCES}

Abell, P. Rational Choice Theory, Brookfield, VT: Edward Elgar, 1991.

Abrahamson, E. "Management Fashions, Academic Fashions and Enduring Truths," The Academy of Management Review (14:27), 1996, pp. 616-619.

Abrahamson, E. "Words into Numbers," Academy of Management Conference Report, Washington, DC, 2001.

Alvarez, J. L. "The International Popularization of Entrepreneurial Ideas," in S. R. Clegg and G. Palmer (Eds.), The Politics of Management Knowledge, London: Sage Publications, 1996, pp. 80-98..

Attewell, P., and Rule, J. "Computing and Organizations: What We Know and What We Don't Know," Communications of the ACM (27:2), 1984, pp. 1184-1191.

Beedham, C. "Language, Indoctrination and Nuclear Arms," University of East Anglia Papers in Linguistics, 1983, pp. 15-31.

Bergman, B. "Wired Revolution," Maclean's (119:3), 1998, p. 66.

Blaug,R. Democracy Real and Ideal: Discourse Ethics andRadical Politics, New York: State University of New York Press, 1999.

Bloomfield, B., and Vurdubakis, T. "Re-presenting Technology: IT Consultancy Reports as Textual Reality Constructions," Sociology (28:2), 1994, pp. 455-477.

Boland, R. J. "Information System Use as a Hermeneutic Process," in H-E. Nissen, H. K. Klein, and R. A. Hirschheim (Eds.), Information Systems Research: Contemporary Approaches and Emergent Traditions, Amsterdam: North Holland, 1991, pp. 439-458.

Boland, R. J. "Phenomenology: A Preferred Approach to Research in Information Systems," in E. Mumford, R. A. Hirschheim, G. Fitzgerald, and A. T. Wood-Harper (Eds.), Research Methods in Information Systems, Amsterdam: North Holland, 1985, pp. 193-201.

Boland, R. J., and Day, W. F. "The Experience of System Design: A Hermeneutic of Organizational Action," Scandinavian Journal of Management (5:2), 1989, pp. 87-104.

Bowring, M. A. "De/Construction Theory: A Look at the Institutional Theory that Positivism Built," Journal of Management Inquiry (9:3), September 2000, pp. 135-137.

Burrell, G., and Morgan, G. Sociological Paradigms and Organizational Analysis: Elements of the Sociology of Corporate Life, London: Heinemann, 1979.

Butler, T. "Towards a Hermeneutic Method for Interpretive Research in Information Systems," Journal of Information Technology (13:4), 1998, pp. 285-300.

Calás, M., and Smircich, L. "Voicing Seduction to Silence Leadership," Organization Studies (12:4), 1991, pp. 567-601.

Cannon, B. Rethinking the Normative Content of Critical Theory: Marx, Habermas and Beyond, New York: Palgrave, 2001.

Chomsky, N. Necessary Illusions: Thought Control in Democratic Societies, Concord, ON: House of Anansi Press, 1989.

Clegg, S. R., and Palmer, G. (Eds.). The Politics of Management Knowledge, London: Sage Publications, 1996.

Cukier, W., and Bauer, R. "The (Re)Production of Technology Discourse: Technology Enabled Learning in Canada," paper presented at the European Group on Organization Studies (EGOS) Conference, Barcelona, Spain, 2002.

Cukier, W., Middleton, C. A., and Bauer, R. "A Critical Analysis of Technology Enabled Learning Discourse in Canada and Its Implications for Policy and Organizational Decision Making," in E. H. Wynn, E. A. Whitley, M. D. Myers and J. I. DeGross (Eds.), Global and Organizational Discourse About Information Technology, Boston: Kluwer Academic Publishers, 2003, pp. 197-221.

Czarniawska-Joerges, B., and Joerges, B. "how to Control Things with Words: Organizational Talk and Control," Management Communications Quarterly (2:2), 1988, pp. 170-193. 
DiMaggio, P., and Powell, W. "The Iron Cage Revisited: Institutional Isomorphism and Collective Rationality in Organizational Fields,"American SociologicalReview (48), 1984, pp. 147-160.

Domet, S. "Turn On, Plug In, Hook Up: At Acadia University, the Computer Revolution Is Changing the Way Students Learn and How Professors Teach," Quill and Quire (63:11), 1997, pp. 1, 17.

Duquenoy, P., Thimbleby, H., and Torrance, S. "Towards a Synthesis of Discourse Ethics and Internet Regulation," School of Computing Science, Middlesex University, London, 1998 (available online at http://www.cs.mdx.ac.uk/staffpages/penny/Habermas.htm).

Ellul, J. "The Technological System," trans. Joachim Neugroschel, New York: Continuum, 1977.

Faerber, M. Gale Directory of Databases, Foster City, CA: Gale Group Publishers, 1999.

Fairclough, N. Critical Discourse Analysis: The Critical Study of Language, New York: Longman Group, 1995.

Feldman, M. S., and March, J. G. "Information in Organizations as Signal and Symbol," Administrative Science Quarterly (26:2), 1981, pp. 171-186.

Fiske, J. An Introduction to Communication Studies, London: Methuen Press, 1982.

Fondas, N. "Feminization Unveiled: Management Qualities in Contemporary Writings," Academy of Management Review (22:1), 1997, pp. 257-282.

Forester, J. "Critical Theory and Organizational Analysis," in G. Morgan (Ed.), BeyondMethod Beverley Hills, CA: Sage Publications, 1983, pp. 234-346.

Forester, J. Planning in the Face of Power," Berkeley, CA: University of California Press, 1989. Foucault, M. Two Lectures: Power/Knowledge, New York: Random House, 1980.

Furusten, S. Popular Management Books: How They Are Made and What They Mean for Organizations, London: Routledge, 1999.

Gerbner, G. "Comparative Cultural Indicatorsm" in G. Gerbner (Ed.), Mass Media Policies in Changing Cultures, New York: Wiley Publishing, 1977, pp. 199-205.

Gopal, A., and Prasad, P. "Understanding GDSS in Symbolic Context: Shifting the Focus from Technology to Interaction," MIS Quarterly (24:3), 2000, pp. 509-546.

Grant, D., Keenoy, T., and Oswick, C. "Organizational Discourse: Key Contributions and Challenges," International Studies of Management and Organization (31:3), 2001, pp. 5-25.

Habermas, J. Communication and the Evolution of Society, trans. T. McCarthy, Boston: Beacon Press, 1979.

Habermas, J. The Theory of Communicative Action, Boston: Beacon Press, 1984.

Halifax Daily News. "Acadia's Wired Students Soar to Top of Class, Study Shows, February 1, 1997, p. 4.

Hansen, A., Cottle, S., Negrine, R., and Newbold, C. (Eds.). Mass Communications Research Methods, New York: New York University Press, 1998.

Hardt, H. Critical Communication Studies. Communication, History and Theory in America, New York: Routledge, 1992.

Hardy, C. "Researching Organizational Discourse," International Studies of Management and Organization (31:3), 2001, pp. 25-48.

Hardy, C. Lawrence, T., and Phillips, N. "Talking Action: Conversations, Narrative, and Action in Interorganizational Collaboration," in D. Grant, T. Keenoy, and C. Oswick (Eds.), Discourse and Organization, London: Sage Publications, 1998, pp. 65-83.

Heracleous, L., and Barrett, M. "Organizational Change as Discourse: Communicative Actions and Deep Structures in the Context of Information Technology Implementation," Academy of Management Journal (44), 2001, pp. 755-778.

Herman, E. S., and Chomsky, N. Manufacturing Consent: The Political Economy of the Mass Media, New York: Pantheon, 1988. 
Hirsch, P. M. "From Ambushes to Golden Parachutes: Corporate Takeovers and an Instance of Cultural Framing and Institutional Integration," American Journal of Sociology (91), 1986, pp. 800-837.

Inglis, F. Media Theory, Oxford: Blackwell, 1990.

Jensen, K. B. "Humanist Scholarship as Qualitative Science: Contributions to Mass Communication Research," in K. B. Jensen and N. Jankowski (Eds.), A Handbook of Qualitative Methodologies for Mass Communication Research, London: Routledge, 1991, pp. 17-43.

Jensen, K. B., and Jankowski, N. (Eds.). A Handbook of Qualitative Methodologiesfor Mass Communication Research, London: Routledge, 1991.

Joy, S. "Mobile Users Plug into University Network: School Plans to Have Program Extended to All 4,000 Students by 2000," Technology in Government (56), 1998, p. 18.

Kets de Vries, M. F. R., and Miller, D. "Interpreting Organizational Texts," Journal of Management Studies (24:3), 1987, pp. 233-247.

Klein, H. K., and Hirschheim, R. "The Application of Neohumanist Principles in Information Systems Development," in D. Avison, T. E. Kendall and J. I. DeGross (Eds.), Human, Organizational and Social Dimensions of Information Systems Development, Amsterdam: Elsevier. 1993, pp. 264-280.

Klein, H. K., and Hirschheim, R. "Rationality Concepts in Information System Development Methodologies," Accounting, Management and Information Technologies (1:2), 1991, pp. 157-187.

Krefting, L. A. "Re-Presenting Women Executives: Valorization and Devalorization in US Business Press," paper presented at the European Group on Organizational Studies (EGOS) Conference, Lyon, France, 2001.

Larsen, P. "Textual Analysis of Fictional Media Content," in K. B. Jensen and N. Jankowski (Eds.), A Handbook of Qualitative Methodologies for Mass Communication Research, London: Routledge, 1991, pp. 121-148.

Lazarsfeld, P. F., and Merton, R. K. "Mass Communications, Popular Taste, and Organized Social Action," reprinted in W. Schramm (Ed.), Mass Communications. Urbana, IL: University of Illinois Press, 1948, pp. 492-512.

Lee, A. S. "Electronic Mail as a Medium for Rich Communication: An Empirical Investigation Using Hermeneutic Interpretation,” MIS Quarterly (18:2), 1994, pp. 143-157.

Lewington.J. "Acadia President's Style Assailed," Globe and Mail, November 18, 1998, p. A6. Lippmann, W. Public Opinion, New York: MacMillan, 1992.

Lyytinen, K. J., and Klein, H. K. "The Critical Theory of Jurgen Habermas as a Basis for a Theory of Information Systems," in E. Mumford, R. Hirschheim, G. Fitzgerald, and A. T. Wood-Harper (Eds.), Research Methods in Information Systems, Amsterdam: North Holland, 1985, pp. 219-237.

McLaughlin, P. “The Learning Curve: St. F.X. Goes High-Tech with New \$8m Network,” The Halifax Daily News, January 19, 1998, p. 6.

McLaughlin, P. "Techno Tools: Do Students Really Need to Be Wired or Are Computers Just a Fancy Distraction from the Basics," Halifax Daily News, February 16, 1997, p. 4.

McLuhan, M., and Fiore, Q. War and Peace in the Global Village, New York: Bantam, 1968.

Meyer, J., and Rowan, B. "Institutionalized Organizations: Formal Sstructure as Myth and Ceremony, American Journal of Sociology (83), 1977, pp. 157-179.

Meyer, J., and Scott, R. (Eds.). Organizational Environments: Ritual and Rationality, Newbury Park, CA: Sage Publications, 1983.

Meyer, J., and Scott, R. (Eds.). Organizational Environments: Ritual and Rationality (rev. ed.). Newbury Park, CA: Sage Publications, 1992.

Michalos, A. C. Improving Your Reasoning, London: Prentice Hall, 1986.

Murphy, M. "Living the Acadia Experiment," Globe and Mail, June 22, 1998, p. C38. 
Murray, F. "Technical Rationality and the IS Specialist: Power, Discourse and Identity," Critical Perspectives on Accounting (2), 1991, pp. 59-81.

Myers, M. D. "Dialectical Hermeneutics: A Theoretical Framework for the Implementation of Information Systems," Information Systems Journal (5:1), 1995, pp. 51-70.

Nardi, B. A. and O'Day, V. L. Information Ecologies: Using Technology with Heart, Cambridge, MA: MIT Press, 1999.

Ngwenyama, O. K. "The Critical Social Theory Approach to Information Systems: Problems and Challenges," in H-E. Nissen, H. K. Klein and R. H. Hirschheim (Eds.), Information Systems Research: Contemporary Approaches andEmergent Traditions, Amsterdam: North Holland, 1991, pp. 267-280.

Ngwenyama, O., and Lee, A. "Communication Richness in Electronic Mail: Critical Theory and the Contextuality of Meaning," MIS Quarterly (21:2), 1997, pp. 145-167.

Noakes, S. "Virtual Classroom Opens its Doors," Financial Post, April 24, 1996, p. 14.

NODE. "LTReport: The Mobile Campus Matures," The Node Learning Technologies Network, 2000 (available online at http://node.on.ca/ltreport/mobile).

Orlikowski, W., and Yates, J. "Genre Repertoire: The Structuring of Communicative Practices in Organizations," Administrative Science Quarterly (39:4), 1994, pp. 541-574.

Päivärinta, T. "The Concept of Genre Within the Critical Approach to Information Systems Development," Information and Organization (11), 2001, pp. 207-234.

Pearsall, K. "Higher Learning via Wired Classes: Technology is Getting Good Grades with Faculty and Students at Acadia University," Computing Canada (24:10), 1998, pp. 11-12.

Phillips, N., and Hardy, C. Discourse Analysis: Investigating Processes of Social Construction, Thousand Oaks, CA: Sage Publications, 2002.

Phillips, N., and Hardy, C. "Managing Multiple Identities: Discourse, Legitimacy and Resources in the UK Refugee System," Organization (4), 1997, pp. 159-186.

Postman, N. Technology: The Surrender of Culture to Technology, New York: Vintage, 1992.

Robey, D., and Markus, M. L. "Rituals in Information System Design," MIS Quarterly (8:1), 1984, pp. 5-15.

Rose, E. User Error: Resisting Computer Culture, Toronto: Between the Lines, 2003.

Sheridan College. "Mobile Briefing," unpublished, May 2000.

Sommers, J. A. "Acadia Students, Professors Meet at the Sandbox," Globe and Mail, August 26, 1997, p. C5.

Stoll, C. Silicon Snake Oil, New York: Anchor Books, 1995.

Tausz, A. "How Technology Firms Court the Key Education Markets," Globe and Mail, October 15, 1996, p. C6.

Townley, B. "Foucault, Power/Knowledge, and its Relevance for Human Resource Management," Academy of Management Review (18:3), 1993, pp. 518-545.

Truex, D. P., and Klein, H. K. "A Rejection of Structure as a Basis for Information Systems Development," in R. K. Stampler, P. Kerola, R. Lee, and K. Lyytinen (Eds.), Collaborative Work, Social Communications andInformation Systems, Amsterdam: North Holland, 1991, pp. 213-235.

Ulrich, W. "A Philosophical Staircase for Information Systems Definition, Design, and Development: A Discursive Approach to Reflective Practice in ISD (Part 1)," Journal of Information Technology Theory and Application (3:3), 2001, pp. 55-84.

Van Dijk, T. A. "The Interdisciplinary Study of News as Discourse," in K. B. Jensen and N. Jankowski (Eds.), A Handbook of Qualitative Methodologies for Mass Communication Research, London: Routledge, 1991, pp. 104-120.

Watters, C., Conley, M., and Alexander, C. "The Digital Agora: Using Technology for Learning in the Social Sciences," Communications of the ACM (41:1), 1998, pp. 50-57.

Weick, K. E. Sense Making in Organizations, Thousand Oaks, CA: Sage Publications, 1995.

Winner, L. The Whale and the Reactor, Chicago: University of Chicago Press, 1986. 
Wodak, R. (Ed.). Language, Power andIdeology: Studies in Political Discourse, Philadelphia: John Benjamins Publishing, 1989.

Wynn, E. H., Whitley, E. A., Myers, M. D., and DeGross, J. I. Global and Organizational Discourse About Information Technology, Boston: Kluwer Academic Publishers, 2003.

\section{ABOUT THE AUTHORS}

Wendy Cukier is a professor of Information Technology Management at Ryerson University in Toronto, a professor in the joint graduate program in Communication and Culture (Ryerson and York), and the Associate Dean (Academic) of the Faculty of Business. She holds M.A. and MBA degrees from the University of Toronto and a Ph.D. from York University. Her research focuses on emerging technology trends, technology discourse and gender. She is the recipient of many awards including two honorary doctorates and the Governor General's Meritorious Service Cross, one of Canada's highest civilian honours, for her advocacy work. Wendy can be reached by e-mail atwcukier@ryerson.ca.

Robert Bauer is an associate professor of Organizational Design and Behavior at Johannes Kepler University Linz, Austria. His research aims at a better understanding of different ways of knowing (including but not limited to explicit formal and every day language statements) and exploring their consequences for organizational design and behavior. He studies aspects of identity and difference on the individual, organizational and inter-organizational level as well as with respect to the philosophy of organization science. He is also a registered psychotherapist and has worked extensively as an executive coach and trainer. Robert can be reached at robert.bauer@jku.at.

Catherine Middleton is an assistant professor of Information Technology Management at Ryerson University in Toronto and also a professor in the joint graduate program in Communication and Culture (Ryerson and York). She holds a Ph.D. from York University and an MBA from Bond University. Her current research interests include consumer usage of broadband technologies, policy related to the development of broadband networks, and consumer adoption of mobile technologies. Catherine can be reached by e-mail at cmiddlet@ ryerson.ca. 


\section{Appendix A}

\section{TEXTS INCLUDED IN THE ANALYSIS}

\begin{tabular}{|l|c|}
\hline Popular Discourse & 25 \\
\hline The Halifax Daily News & 6 \\
\hline The Globe and Mail & 2 \\
\hline Macleans & 1 \\
\hline The Toronto Star & 1 \\
\hline Canadian Business & 1 \\
\hline Edmonton Journal & 1 \\
\hline Times Colonist & 1 \\
\hline Briarpatch & \\
\hline Financial Post Daily & 2 \\
\hline Academic Discourse & \\
\hline Communications of the ACM & \\
\hline Practical Discourse & 2 \\
\hline Systems: & 2 \\
\hline Computing Canada & 1 \\
\hline Computer-dealer News & 1 \\
\hline Canadian Telecom & 1 \\
\hline Technology in Government & \\
\hline Network World Canada & 1 \\
\hline Teaching/Administration: & 1 \\
\hline University Affairs & \\
\hline Campus Canada & 1 \\
\hline Other: & \\
\hline Quill and Quire & 1 \\
\hline Peace Research & \\
\hline Parks and Recreation Can. & \\
\hline Total & \\
\hline
\end{tabular}

